\title{
The Prosecution Role where Courts Decide Cases
}

\author{
Marianne Wade • Paul Smit • \\ Bruno Aubusson de Cavarlay
}

Published online: 29 July 2008

(C) Springer Science + Business Media B.V. 2008

\begin{abstract}
This article explores the role played by prosecutors during the court stage of criminal proceedings. It complements Peter et al.'s chapter on negotiated case settlements in showing how the power to decide cases is divided between judges and prosecutors when cases are taken to court. Providing information as to, e.g. what influence prosecutors in the 11 study countries have on what evidence is brought to court in "normal" and accelerated court proceedings, this chapter explores the balance of responsibilities in court rooms across Europe.
\end{abstract}

Keywords Balance of power judges/prosecutors · Court criminal proceedings · Role played by prosecutor

The study which forms the focus of this thematic issue focuses upon the role of prosecution services and thus centrally upon their independent powers. However, as we shall see, to neglect to observe also the balance of power in working with other institutions, would be to oversee much of the information which provides key insights into what public prosecutions services really are (see also Wade 2006).

The court/prosecution service relationship is one such instance and is, for the most part, explored in the following. It is indicative of the complex nature of this relationship that

M. Wade $(\bowtie)$

Max Planck Institute for Foreign and International Criminal Law, Günterstalstr. 73,

79100 Freiburg i.B., Germany

e-mail:m.wade@mpicc.de

P. Smit

Research and Documentation Center (WODC) of the Ministry of Justice,

P.O. Box 2031, 2500 EH The Hague, Netherlands

e-mail: p.r.smit@minjus.nl

B. Aubusson de Cavarlay

Center for Sociological Research on Law and Penal Institutions (CESDIP), Ministère de Justice/CNRS,

43 Boulevard Vauban, F-78280 Guyancourt (Paris), France

e-mail: bruno@aubusson.net 
Table 1 Alternative adjucative procedural forms overview

$\begin{array}{lll}\begin{array}{ll}\text { Penal order (true court decision) } \\ \text { Negotiated case-ending }\end{array} & \text { During pre-trial stage } & \mathrm{CH}, \mathrm{PL} \\ \text { settlement } & \text { During trial } & \mathrm{E}(1)^{1}, \mathrm{HR}^{2}, \mathrm{~F}(\mathrm{CRPC}), \mathrm{PL}(1)^{3} \\ & & \mathrm{E}(2)^{4}, \mathrm{E}(3)^{5}, \mathrm{EW}, \mathrm{H}^{6}, \mathrm{HR}^{7}, \mathrm{PL} \\ \text { Accelerated proceedings } & \text { Simplification in pre-trial stage } & (2)^{8} \\ & \text { Simplification during interlocutory } & \mathrm{D}^{10}, \mathrm{E}(4)^{12} \\ & \text { proceedings } & \\ & \text { Simplification during trial } & \mathrm{EW}, \mathrm{HR} \\ \text { Judge joining proceedings in court } & \mathrm{CH}, \mathrm{D}, \mathrm{E}^{12}, \mathrm{EW}, \mathrm{F}, \mathrm{NL}, \mathrm{H}, \mathrm{HR}, \\ & \mathrm{S}, \mathrm{TR}\end{array}$

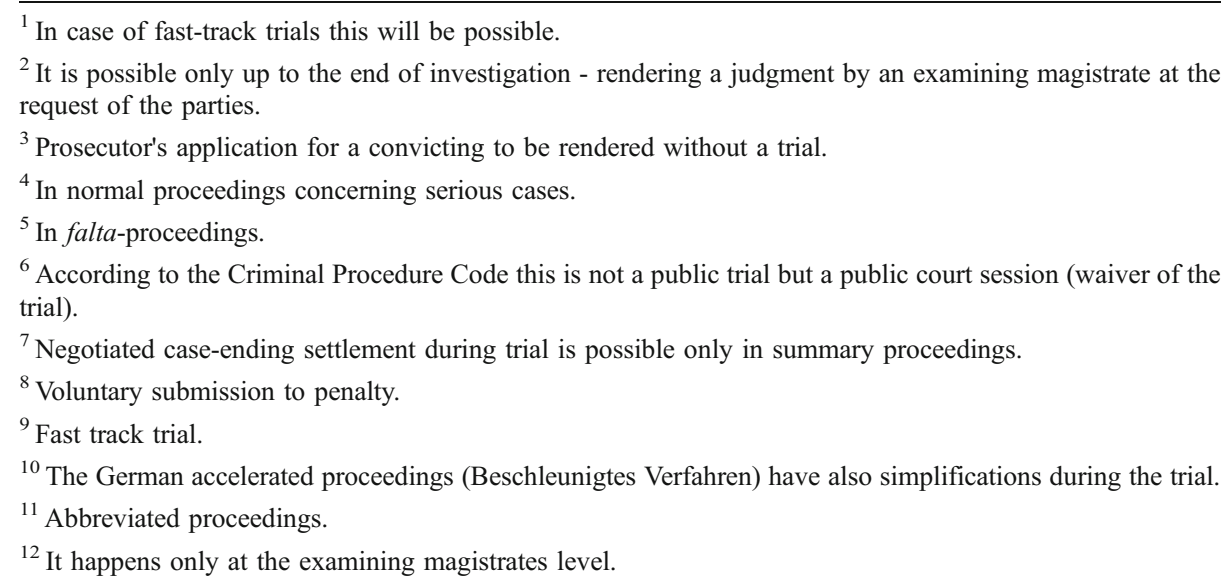

some decisions made by courts (penal orders) are not explored in this chapter but under that on prosecutorial options (see Jehle et al. 2008) because this study evaluates them as effectively being prosecution service decisions in half the jurisdictions in which they are available (namely in Germany, France and Croatia ${ }^{1}$ - see Table 1 in Jehle et al. (2008), whilst in Switzerland (Canton Basel-Stadt), Poland and Hungary it is regarded as a true court decision - see Table 1), such is the extent of prosecutorial influence upon courts making them. The question explored here is in how far other court decisions are influenced by prosecutorial actions or in other words, what the courts' role within Europe's criminal justice systems is. Table 1 shows which types of court proceedings are available alongside full court proceedings.

\section{Full Criminal Proceedings}

Each of the criminal justice systems explored in this study has a form of standard criminal proceedings regarded as the norm by the rules of criminal procedure (though it may statistically be wrong to refer to it as "normal" criminal proceedings). They entail the full

\footnotetext{
${ }^{1}$ Although legally the penal order is a court decision, it might be effectively seen as a PPS sanction because the court usually agrees with the PPS proposal. According to 2000 research the court rejected a penal order application and initiated main hearings only in $3.9 \%$ of cases.
} 
Table 2 Which Institution can join Cases?

PPS

CH, E, EW, D ${ }^{1}, \mathrm{~F}, \mathrm{H}, \mathrm{HR}, \mathrm{NL}, \mathrm{PL}, \mathrm{TR}, \mathrm{S}$

Only court

Other

Court

CH, E, EW, D, F, H, HR, NL, PL, TR, S

${ }^{1}$ Proceedings can be merged with others during the investigative stage as well as at court level.

procedural protective mechanisms intended for the defendant and provide for the full implementation of principles of transparency (i.e. a public trial) and immediacy as foreseen within the system. They are the legal norm from which all alternative procedural forms deviate.

The traditional prosecution service role includes preparing cases for such proceedings. The simplest means by which the PPS prepares a case and at the same time ensures court time is used efficiently, is to join cases against the same defendant to be heard in the same hearing. Table 2 shows the PPS as entrusted to do so in all the systems studied. Interestingly though, Table 1 shows that in all systems bar the Polish one the courts also have this power. In other words, almost all of them provide for cases in which the PPS may not have discovered that a suspect has more than one case to answer to, to be remedied by the courts.

As Table 3 shows, the PPS is not without influence upon full criminal proceedings. It is always influential in deciding what charge to bring: only in Spain is this decision made together with a judicial instance (the investigating magistrate). Only in England and Wales and Sweden and in less serious cases in Switzerland does the role expected of the PPS deviate from that of an objective body within a classically inquisitorial set-up. The PPS is a service expected to provide full evidence and to help to discover the truth, etc. Only in Spain is the PP not active in presenting evidence. A sentencing suggestion will be made by the PPS in all jurisdictions except England and Wales and Croatia. European PPSs have appeal powers which can be used as a check upon courts.

Croatia The court is bound by the charge (as to the person and act charged) brought by the prosecutor. However, the court may change the original PPS legal evaluation of the offence committed. This does not happen all too often. The 1998 Criminal Procedure Act provided for a more active role to be played by the parties, never the less the prosecutor still tends to be active only in presenting evidence - usually orally - to support the prosecution case and it is the judge who mainly leads the proceedings, summons additional witnesses and considers further evidence as s/he sees fit. In his or her closing argument, the prosecutor presents his/her substantiated motion regarding aggravating and mitigating circumstances which should be taken into account in sentencing. The prosecutor is not entitled to propose the level of punishment, but s/he may propose that the court order a judicial admonition or suspended sentence. The PPS launches appeals against courts' decisions before they become final and submits extraordinary judicial remedies against final court decisions. The PPS may file an appeal to the prejudice or to the benefit of the accused. The PPS may challenge a judgement for substantive violation of the criminal procedure provisions, violation of the Criminal Code, for erroneous or incomplete determination of the factual situation and with regard to the decision on criminal sanctions, confiscation of pecuniary benefit, costs of criminal proceedings, claims for indemnification as well as the decision to publish the judgement in the media. The proportion of cases ended by full "normal" trial is 
Table 3 PPS' influence upon and role during a full trial

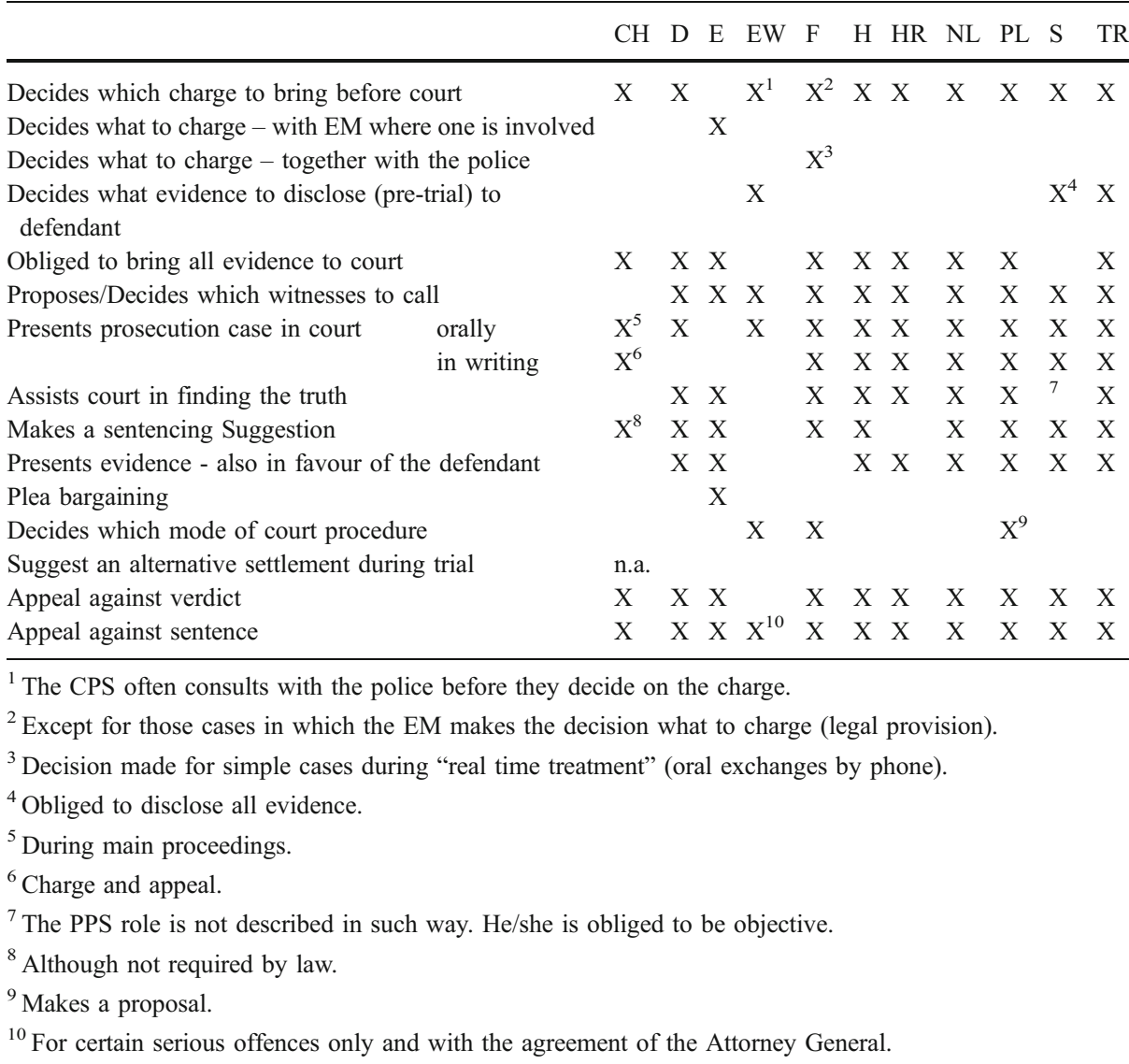

very low. In 2006 only in $9.88 \%$ of cases in which PPS has brought charges normal proceedings, with indictment and main hearing, were conducted (see also Turković 2008).

In England and Wales the CPS has only recently taken over charging. Courts have always changed charges themselves, 'putting right' what the police have proposed in the way of charging. The change to the CPS is too recent to know whether the courts are intervening more or less than they did before. In theory giving more legal attention to the charging process should result in its being more efficient and fewer occasions when the court has to overrule the charge brought before it. Indeed, the move to CPS charging has brought about an increase in the proportion of police cases that proceed to a court hearing.

However, the CPS has a lesser role in the court process than the PPS in most other jurisdictions. It does present cases, but, until recently only in the lower courts, with higher court cases being presented by private lawyers retained by the CPS. The CPS makes no statement about sentencing, unless to correct the judge if a mistake is likely to be made. However, if the CPS feels that a sentence is too lenient, it can appeal the length of the sentence imposed, at least for serious cases. This is done in a small number of carefully chosen cases each year, to ensure judges will notice these cases and take appropriate action 
when similar cases arise. All public bodies in England have a statutory duty to avoid discrimination and achieve equality of treatment in the courts: the CPS approaches this in two ways, although the actual level of the sentence does not have a high profile in this work:

1. By publishing impact assessments of their policies on different communities

2. By setting up an independent body in each area to examine a handful of cases after completion and report on their diversity aspects.

Around $50 \%$ of cases brought by the police to the CPS result in a charge: the rest are completed in various different ways. In most of these $50 \%$ the defendant pleads guilty as charged and the case proceeds in a truncated way (see also Lewis 2006).

In France courts are entirely free to change the charge brought by the prosecution service though this probably happens rarely. The role played by prosecutors varies significantly with the type of court and procedure the prosecutor is acting in front of. In particular the balance of written to oral evidence is subject to variation and the prosecutor role is different depending on whether a juge d'instruction is involved or whether the procedure foresees police involvement. Similarly the prosecutor's influence upon the evidence brought to court varies with the type of proceedings and despite the formal requirement that the PPS also bring exonerating evidence for the defendant, this is usually the defence role. A prosecutor will only exceptionally not ask for a specific sentence; this demand usually starts the sentencing process. The PPS has powers to appeal against a verdict and against sentence. About $30 \%$ of cases in which the offender is know were brought to court by normal trial in 2004 (see also Aubusson 2006).

The German courts are free to make an entirely different legal evaluation of the facts at hand and so can change the PPS charge but this does not happen all too often. As an institution bound to be objective the PPS has many obligations relating to this but will play a supporting role to the judge. The prosecutor tends to be active only in presenting evidence - usually orally - to support the prosecution case but it is always the judge who leads the proceedings and s/he will summon additional witnesses and consider further evidence as $\mathrm{s} / \mathrm{h}$ e sees fit. The prosecutor makes a sentence suggestion but courts are free to deviate from this and often do in giving a lesser sentence. The PPS uses its rights to appeal only to object to the crassest court mistakes concerning verdict and sentence. A relatively low proportion of cases dealt with by the German CJS are dealt with via full court proceedings. In 2004 it was 12\% (see Figure 2 in Jehle et al. 2008, see also Elsner and Peters 2006).

Hungarian courts are bound by the charge brought by the PPS, but the judge may reclassify the charge contained in the indictment even during the stage of preparation for the trial if it is necessary. In the final decision the court may evaluate the facts differently in the light of evidence examined at the trial. Although there are no statistics on this we can say that this does not happen too frequently.

The prosecutor is obliged to consider both the circumstances aggravating and extenuating for the defendant and the circumstances aggravating and mitigating the criminal liability in all phases of the proceedings. An objectiveness of the public prosecutor is not usually obvious for participants, in most cases he seems to be only a representative of the charge. But for example in his closing speech the PP has to mention all relevant circumstances against and for the accused and he has the right to legal remedy not only against but for the accused. The appeal of the public prosecutor may concern the implementation of law and sentence (sanction) too.

The charge shall be proven by the accuser who in most cases is the public prosecutor. But if the court deems the results of the evidentiary procedure insufficient, it may, either ex officio or upon a motion order to take or obtain further evidence. 
The prosecutor may amend, expand the indictment or drop the charge even at the trial.

In his/her closing speech the PP puts forward a motion to the court for the type of punishment to be imposed or measure to be applied, but may not propose specifically the extent of the punishment or measure.

In 2005 less than $65 \%$ of accused persons were brought to a full trial (see also Róth 2008).

A little over $50 \%$ of all more serious cases (i.e. all crimes and also economical and environmental infractions) in the Netherlands end in court proceedings with a verdict from a judge. Penal orders are not known, the remaining cases end in a 'real' prosecutors decision (drop or conditional disposal). While the PPS is responsible for everything happening in the investigative phase (with only a minor role played by the examining magistrate) in court proceedings, it is the judge who has the leading role. It is primarily the judge who examines evidence and questions the accused, witnesses and experts. The role of the PPS during trial is more passive, i.e to give the judge all the information collected in the investigation phase.

In practice, however, the PPS does have some influence on court proceedings. Firstly, most of the evidence presented to the court by the PPS (including written statements by witnesses and experts) will hardly be discussed at any length during trial. This is why court proceedings in the Netherlands are usually brief. Secondly, only the PPS decides on the charge and this can not be changed during trial; neither by the prosecutor (except for some exceptional circumstances), nor by the judge. Thirdly, the PPS will propose a sentence in his closing speech and although the actual verdict can be higher or lower, the judge will normally use this proposed sentence as the starting point for his decision.

The PPS uses its right to appeal primarily in the case of not-guilty verdicts. Nine out of ten of the appeals relating to a guilty verdict are initiated by the defence (see also Blom and Smit 2006).

In Poland it is always a judge who leads the proceedings. A prosecutor plays they role of a party to proceedings. He/she should be objective and active during trial, but once a charge has gone to court the activity of prosecutors has in practice the aim to confirm the statements of the indictment. It is of course hard to maintain the principle of objectivity bearing that aim in mind. A prosecutor has no influence upon the judge who is the instance deciding what evidence to hear. A prosecutor's application to hear evidence is, however, hardly ever rejected - as an omission to hear evidence is an "easy" ground for appeal. The court's right to gain further evidence is usually used on behalf of parties to a trial, especially the accused, who will actively request this. It is possible that a court modifies the charge brought, it does not however occur often (there are no statistics concerning this matter). In Poland a prosecutor usually suggests a more severe sentence than $\mathrm{s} / \mathrm{he}$ expects the court to hand down. A lesser sentence does not cause a prosecutor to lodge an appeal. The right to appeal is used by prosecutors in less than $1 \%$ of sentences (about $60 \%$ of appeals are successful). Prosecutors lodge appeal in both situations: to correct implementation of law and to obtain equality of sentencing (concerning the second scenario: more often where a punishment is too mild). In 2005 there were about $46 \%$ cases taken for full trial by the CJS. This is a comparatively high rate (see also Bulenda et al. 2006).

The investigative stage in Spain is held and directed by the Examining Magistrate (EM). During that stage, the PPS and the defence can ask the EM to perform the acts necessary to support their case. However, the final decision remains with the EM. Once the investigative stage is finished, the PPS presents a written indictment (or a written statement asking for the acquittal of the accused), while the defence lawyer prepares its written defence. Depending on the type of proceedings, the EM or the trial court, will then decide if there are grounds for it to proceed (i.e. to the trial stage) or whether it should be dismissed. During the trial stage, the 
functions of the PPS include presenting the case orally, asking the witnesses questions and presenting their final argument summarising the prosecution position in the case. They are allowed to modify their indictment. Finally, whenever the sentence imposed is not the one asked for by the PPS, the PPS has the right to appeal. In sum, in Spain, the functions of the PSS are very similar to the ones of the defence lawyer. The only exceptions to this rule are the rare cases when an offence is reported directly by the citizens to the PPS. Data is not available as to which proportion of cases was tried in which form (see also Aebi and Balcells 2008).

It must be noted that in Switzerland it is usually the prosecutor or the examining magistrate who is competent to issue penal orders in the Canton of Basel-Stadt, used as exemplary for most of this study, they are, however, issued by a judge. The prosecutor tends to be active only in presenting evidence - usually orally - to support the prosecution case but it is always the judge who leads the proceedings and s/he will summon additional witnesses and consider further evidence as $\mathrm{s} /$ he sees fit. The prosecutor makes a sentence suggestion but courts are free to deviate from this (see also Gilliéron and Killias 2008).

The PPS in Sweden retains its position of dominus litis during the entire trial, up to the moment a judgment is made. The PPS may withdraw the charge or terminate a prosecution. (the injured party may, however continue prosecution by oneself.) The court is bound by the charge and cannot go beyond the boundaries set by the PPS' description of the crime prosecuted. The legal qualification of the act, however, is fully in the hands of the court. The maxim "iura novit curia" is valid. In practice, changes to legal qualification of the act by courts are not unusual, but it is not possible to provide a precise figure in this respect. During trials, the court directs proceedings, but the PPS (and defence lawyer) are intended to play the most active roles. The court may decide on its own initiative that new evidence should be submitted, but this does not happen very often (see also Zila 2006).

During a full trial it is the court who is master of proceedings in Turkey. The PPS can submit evidence and demand that the court gather further evidence. The court is not obliged to follow such demands. PPS influence upon a full trial is limited though at the end a prosecutor must express an opinion as to whether a conviction or an acquittal should ensue. In practice a prosecutor pleading for acquittal will hold great sway and usually be followed by a court. Where a prosecutor pleads for a conviction this is an entirely different matter. In 2005 the PPS brought the case to court in $32.7 \%$ of cases. $55 \%$ were dropped or disposed of and the remaining cases were subject to alternative decisions (such as to transfer the case to another PPS). The courts convicted in $40.8 \%$ and acquitted in $22.2 \%$ of cases. In $37 \%$ other solutions (such as disposals) were chosen (see also Hakeri 2008).

Thus it is clear that whilst full criminal trials are primarily the courts' field of influence within Europe, in a few countries, especially the Netherlands a significant PPS influence is to be seen because of the extent to which prosecutors influence what evidence is heard. Where the courts are asked to decide, their decisions are respected; this can be seen in particular because although most prosecution services have suitable appeal powers, these are only rarely used in such a way that the PPS can be regarded as a kind of control instance for the courts.

The statistics show the courts as playing a major role in dealing with cases within the criminal justice system in England \& Wales (though this can be contested due to the high incidence of guilty pleas), Hungary (though the high incidence of accelerated proceedings among these cases leaves questions about the balance of power open) and Poland, whilst the low proportion of cases brought to full trial in Croatia and Germany certainly provide some indication of a wider ambit of prosecutorial power, i.e. a greater prosecutorial role within the CJSs there. 
Table 4 PPS' role in accelerated proceedings

\begin{tabular}{|c|c|c|c|c|c|c|c|c|c|c|}
\hline & $\mathrm{CH}$ (n.a.) & $\mathrm{D}$ & $\mathrm{E}$ & EW & F (n.a.) & $\mathrm{H}$ & HR & NL & PL S (n.a.) & TR (n.a.) \\
\hline $\begin{array}{l}\text { Written evidence only - PPS } \\
\text { prepares case }\end{array}$ & & & & $\mathrm{X}$ & & & & & & \\
\hline $\begin{array}{l}\text { Effectively pre-forms } \\
\text { court decision }\end{array}$ & & & & $\mathrm{X}$ & & & & & & \\
\hline $\begin{array}{l}\text { Suggests a sentence } \\
\text { which court can only } \\
\text { accept or reject } \\
\text { proceedings entirely }\end{array}$ & & & & & & & & & & \\
\hline Written charge & & & $\mathrm{X}$ & & & & $\mathrm{X}^{1}$ & $\mathrm{X}$ & & \\
\hline $\begin{array}{l}\text { Written charge in standardised } \\
\text { form }\end{array}$ & & & & $\mathrm{X}$ & & & & & $\mathrm{X}$ & \\
\hline Lodges charge orally & & $\mathrm{X}$ & & & & $X^{2}$ & & & & \\
\hline
\end{tabular}

\footnotetext{
${ }^{1}$ The State Attorney may submit a motion to indict merely upon a crime report without investigation. The motion to indict shall state the type and measure of a legal sanction requested to be passed, however this is not mandatory for court.

${ }^{2}$ And PP gives a document (simplified indictment) called ,record"to the court.
}

\section{Accelerated Proceedings}

As Table 1 shows, one of the procedural alternatives found in several of the criminal justice systems studied are accelerated proceedings. This is an umbrella term used within this study to refer to a variety of procedural forms which increase the efficiency of criminal procedure by omitting certain steps required in full criminal proceedings either pre-trial or during the trial itself. Table 1 also provides an overview of the procedural short-cuts taken in the various jurisdictions.

In most cases these provide for relatively small efficiency increases; only in England and Wales are such changes regarded as amounting to effectively pre-forming a court decision. These efficiency gains are summarised in Table 4.

As Table 5 shows, the use of such proceedings is limited to simple and clear cases, except in Croatia, only in Hungary is a confession by the defendant required. Often the use of such proceedings is limited to offences for which only a relatively low sentence is demanded; only in England and Wales and the Netherlands is it restricted by a catalogue of offences. Usually the court is required to check whether the pre-conditions for use are fulfilled. It may well be the absence of this kind of check which allows such proceedings to be used to effectively pre-form the court decision in England and Wales. The relatively low gains in efficiency terms associated with such proceedings in most jurisdictions presumably explains the comparatively low rates of use, also underlining a theory that criminal justice systems are primarily introducing and utilising alternative procedural forms to enable cases to be dealt with more efficiently.

Accelerated proceedings apply in Croatia in proceedings before a municipal court for offences punishable by fine or imprisonment for a term less than five years as a principal punishment. It is neither a matter of choice for the PPS to initiate accelerated proceedings in such cases, nor may the court disagree with use of accelerated proceedings if the legal requirements for the proceedings are met. For years around $90 \%$ of all charged cases are conducted according to accelerated proceedings. The procedure is simpler with less formality. 
Table 5 Conditions for the use of accelerated proceedings

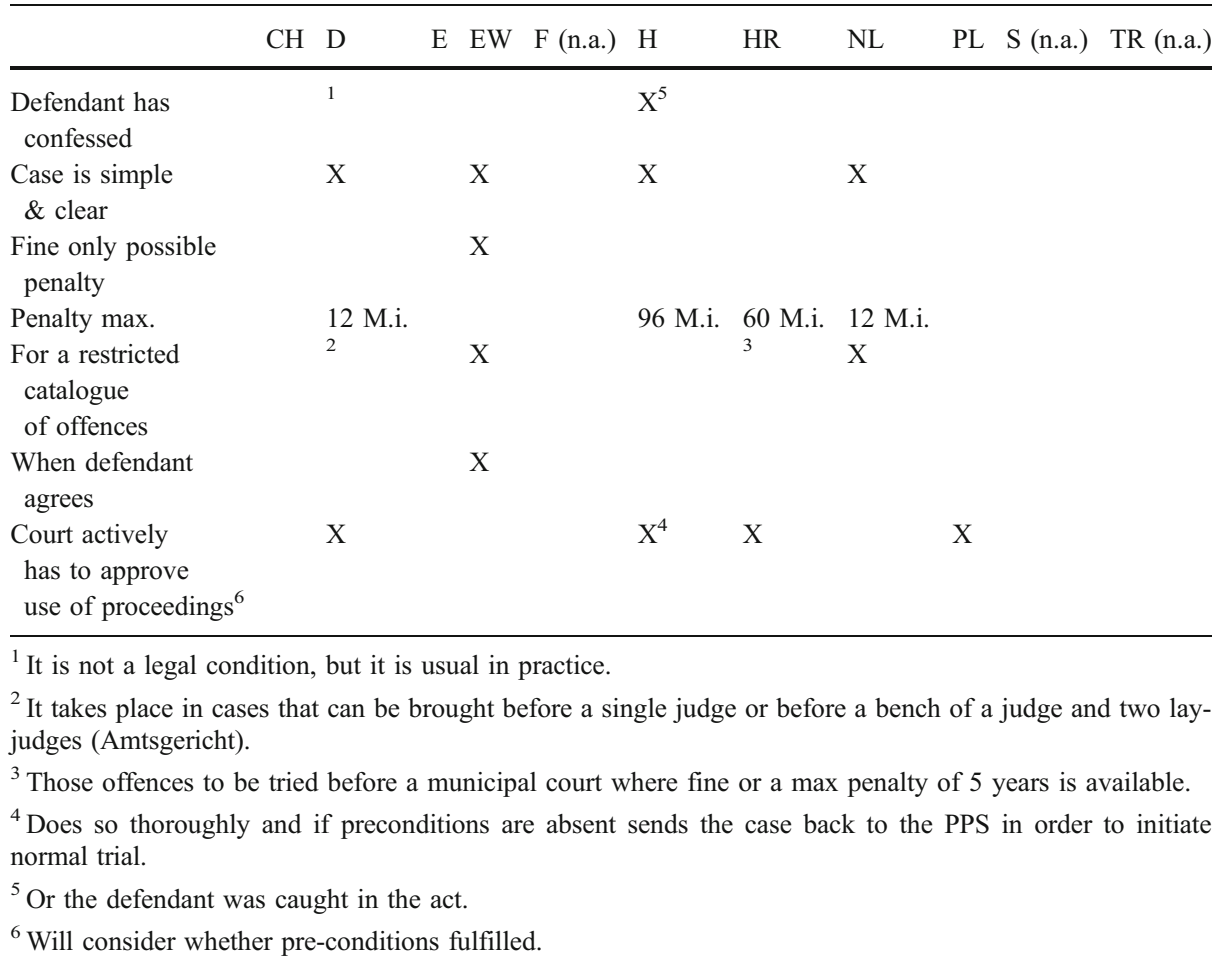

England and Wales lower courts bundle together similar cases that have achieved a guilty plea, usually by post, which will lead to a fine. These cases are 'nodded through' in a form of accelerated proceedings and include many traffic cases (speeding, disobeying traffic signs and lights) and small offences of licence evasion.

Accelerated proceedings are available in Germany but only allow the intermediary court stage to be skipped. Thus they do not provide an efficiency benefit regarded as worthwhile and are used only in 1\% of all cases dealt with by the PPS in 2004.

Three types of accelerated, simplified procedures are available in Hungary: arraignment, omission of the trial and waiver of the trial ("penal order"). In 2005, 104,647 offenders were accused by the public prosecutor and brought before the court. The prosecutor made a motion in the indictment for the omission of the trial by the court in respect of $26.2 \%$ of suspects and $8.9 \%$ of the accused were dealt with by arraignment. The prosecutor initiated waiver of the trial in the indictment lodging for adjudication of the case in a public session in the procedure against only 448 suspects $(0.4 \%$ of all offenders-Data in tables and footnotes regards arraignment as accelerated procedure).

Although court proceedings in the Netherlands are already reasonably efficient mainly because written evidence is accepted, the PPS has also the choice of bringing the case to a single judge instead of a full bench (of three judges). In practice this will happen in the vast majority of cases, the only restriction is that the maximum sentence that can be imposed by this single judge is 12 months imprisonment. Also, if the (single) judge is of the opinion that the case is complicated he can redirect the case to a full bench. 
Accelerated proceedings were introduced in the Spanish criminal justice system through a reform of the Criminal Procedure Code in 2002. Only some offences can be the object of this kind of proceedings and several conditions need to be fulfilled in order to apply them. The main innovation is that, under special circumstances, it is the Examining Magistrate who pronounces directly the sentence instead of transmitting the case to a second instance. Thus the whole duration of the proceeding can be reduced to a few days only. According to the latest available statistical data, 9092 cases were tried through accelerated proceedings in Spain in 2005.

No such proceedings are available in France (though there are means to bring matters to trial more speedily and see also discussion in Peters et al. 2008), Switzerland (Basel-Stadt), Sweden or Turkey.

\section{Conclusion and Evaluation}

As the above analysis shows, one must explore the PPS/court relationship in order to legitimately determine the PPS role within a criminal justice system. As has been shown here, the PPS can certainly be said to have a role supporting the courts in its work, sometimes exercising such influence that the courts' ability to master their workload must in some ways be attributed to preparatory work by the PPS. It is important to recognise the far-reaching influence the PPS has in such systems.

As the analysis in Jehle et al. (2008) shows, prosecutorial discretionary and courts' primarily prosecution influenced decisions are used to deal with less serious offences. Logically it is therefore clear that the types of court decision procedures described above are used to deal with more serious types of offences. Thus the prosecution service can be seen in many ways as the courts' filter, ensuring these have enough time to deal with those cases which, it is judged, truly require their attention via the full and public proceedings brought. Where this is detailed by guidelines it can be seen as a political decision allocating resources within the criminal justice system. Where guidelines are not used, this could well be argued to be a prosecution service decision, although it is likely to be strongly influenced by the seriousness of offences and what volume of cases the courts are capable of dealing with. The use of the negotiated case-ending options described in the following (see Peters et al. 2008) could, however, also be challenging this pattern. Whereas before such measures became available the courts dealt with all serious offences, these proceedings allow these to be dealt with by a simplified procedural route which Peters et al. 2008 judge to be placing them effectively in prosecutorial hands in many cases with lesser court control ensuing. Thus it is likely that the courts role is being changed again: they will be used for full trials to judge cases in which the prosecutor was unable to or felt it unsuitable to negotiate with the defence. In other words it may well be that full court intervention is reserved not just for cases of the most serious nature but those involving either non-co-operative defendants or those the prosecution deems unworthy of a reduced sentence. This is a development which must be explored further; whilst such proceedings are undoubtedly being introduced and used for efficiency reasons, their use may well have further-reaching consequences for how criminal justice systems categorise and punish offenders. By these means defence strategy and moral or other judgements by prosecutors can lead to quite different punishments being imposed for a similar offence. Thus the court/prosecution service relationships within Europe require close observation in order to understand how and what kind of criminal justice is actually being done. 


\section{References}

Aebi, M., \& Balcells, M. (2008). The prosecution service function within the Spanish criminal justice system. European Journal on Criminal Policy and Research, 14(2-3), 311-331.

Aubusson de Cavarlay, B. (2006). The prosecution service function within the French criminal justice system. In Jehle/Wade Coping with overloaded criminal justice systems - The rise of prosecutorial power across Europe. Berlin: Springer, pp. 185-205.

Blom, M., \& Smit, P. (2006). The prosecution service function within the Dutch criminal justice system. In Jehle/Wade Coping with overloaded criminal justice systems - The rise of prosecutorial power across Europe. Berlin: Springer, pp. 237-256.

Bulenda, T., Gruszczynska, B., Kremplewski, A., \& Sobota, P. (2006). The prosecution service function within the Polish criminal justice system. In J. M., Jehle, M., \& Wade (Eds.), Coping with overloaded criminal justice systems (pp. 257-284). Berlin: Springer.

Elsner, B., Peters, J. (2006). The prosecution service function within the German criminal justice system. In Jehle/Wade Coping with overloaded criminal justice systems - The rise of prosecutorial power across Europe. Berlin Heidelberg New York: Springer. pp. 207-236.

Gilliéron, G., \& Killias, M. (2008). The prosecution service function within the Swiss criminal justice system. European Journal on Criminal Policy and Research, 14(2-3), 333-352.

Hakeri, H. (2008). The prosecution service function within the Turkish criminal justice system. European Journal on Criminal Policy and Research, 14(2-3), 353-368.

Jehle, J.-M., Smit, P., \& Zila, J. (2008). The public prosecutor as the key player: Prosecutorial case-ending decisions. European Journal on Criminal Policy and Research, 14(2-3), 161-179.

Lewis, C. (2006). The prosecution service function within the English criminal justice system, In:Jehle/Wade Coping with overloaded criminal justice systems - The rise of prosecutorial power across Europe. Berlin: Springer, pp 151-184.

Peters, J., Aubusson de Cavarley, B., Lewis, C., \& Sobota, S. (2008). Negotiated case-ending settlements: Ways of speeding up the (court) process. European Journal on Criminal Policy and Research, 14(2-3), $145-159$.

Róth, E. (2008). The prosecution service function within the Hungarian criminal justice system. European Journal on Criminal Policy and Research, 14(2-3), 289-309.

Turković, K. (2008). The prosecution service function within the Croatian criminal justice system. European Journal on Criminal Policy and Research, 14(2-3), 263-287.

Wade, M. (2006). The power to decide - prosecutorial control, diversion and punishment in European criminal justice systems today. In Jehle/Wade Coping with overloaded criminal justice systems: Berlin: Springer, pp. 27-126.

Zila, J. (2006). The prosecution service function within the Swedish criminal justice system pp. $285-311$. Berlin: Springer. 